in COPD in the lung tissue and bronchi, especially of small caliber.

CT can serve as a non-invasive method for detecting morphological changes in the lungs in the early stages of COPD, which makes it possible to prescribe adequate treatment in a timely manner and judge the effectiveness of the therapy. Thus, the most informative method of radiation diagnosis of chronic obstructive pulmonary disease is inspiratory-expiratory CT.

\section{LITERATURE}

1. Abdullaeva M.N., Mardieva G.M., Kudratova M.P. Clinical and functional indicators during the period of reparation for complicated pneumonia in children // Ilmiy-amaliy journal "Pediatrics" - T., 2017. - No. 2. - P. 26-29.

2. Aisanov Z.R., Kokosov A.N., Ovcharenko S.I. Chronic obstructive pulmonary disease. Federal Program // Russian Medical Journal. - 2001. - T. 9, No. 1 (120). - S. 9-34.

3. Emelyanov A. V. Diagnosis and treatment of exacerbations of chronic obstructive pulmonary disease // Russian Medical Journal. - 2005. - T. 13, No. 4. - S. $183-189$.
4. Clinical recommendations. Chronic obstructive pulmonary disease / ed. A.G. Chuchalina.- M .: Atmosphere, 2003 .-- 168 p.

5. Momot N.V., Pervak M. B., Vysotsky A. B. The role of multislice computed tomography (MSCT) in the diagnosis of pulmonary pulmonary emphysema / Nevsky Radiological Forum 2011 / Ed. L.A. Tyutin. St. Petersburg: ELBII - St. Petersburg, 2011 .-- S. 137138.

6. Trishina NN, Vitko NK, Zubanov A.G. Computed tomography in the diagnosis of chronic obstructive pulmonary diseases / Diagnostic and interventional radiology: materials of the $\mathrm{V}$ AllRussian National Congress of Radiologists and Therapists. - M., 2011. - No. 2. - S. 439-440.

7. Turdumatov Zh.A., Mardieva G.M., Fayzieva D.O., Yanova E.U. Improving the radiation diagnosis of chronic obstructive pulmonary disease / "Trends and prospects for the development of science and education in the context of globalization": Sat. scientific labor. Pereyaslav-Khmelnitsky, 2019.- No. 44. - C 538-541.

8. Yusupov Sh.A., Mardieva G.M., Bakhritdinov B.R. Features of $\mathrm{x}$-ray semiotics in pneumonia in young children // Scientific-practical journal "Actual nutrition of pediatrics, obstetrics and gynecology" - Ternopol, 2017. - No. 2 (20). - S. 21-24.

\title{
PROGNOSIS OF HEMODYNAMIC EFFICACY IN PATIENTS WITH ARTERIAL HYPERTENSION WITH VARIOUS HELIOTROPIC REACTIONS
}

DOI: $10.31618 /$ ESU.2413-9335.2020.3.72.636

Shadmanova Nargis $K$.

Bukhara State Medical Institute

\section{ПРОГНОСТИКА ГЕМОДИНАМИЧЕСКОЙ ЭФФЕКТИВНОСТИ У БОЛЬНЫХ АРТЕРИАЛЬНОЙ ГИПЕРТОНИЧЕСКОЙ БОЛЕЗНЬЮ ПРИ РАЗЛИЧНОЙ ГЕЛИОТРОПНОЙ РЕАКЦИИ}

\author{
Наргис Курбановна Шадманова \\ Бухарский государственный медииинский институт
}

\begin{abstract}
The article is dedicated to the study of the position of hemodynamic figure in patients with II-stage of arterial hypotension disease with the help of moxonidin and bisoprolol treatment. 49 patients aged from 32 to 60 years old with arterial hypotension disease were examined. All the patients were provided with echocardiography. It is proved that moxonidin has more positive impaction in hemodynamic figure rather than bisoprolol.

\section{АННОТАЦИЯ}

Статья посвящена изучению статуса гемодинамических данных у пациентов с артериальной гипотензией II стадии с помощью лечения моксонидином и бисопрололом. Обследовано 49 пациентов в возрасте от 32 до 60 лет с артериальной гипотензией. Всем пациентам была предоставлена эхокардиография. Доказано, что моксонидин имеет более положительное влияние на гемодинамику, чем бисопролол.
\end{abstract}

Keywords: hemodynamic, prognosis, reaction, heliotrope, aged, impaction, hypotension, disease, differentiated approach.

Ключевые слова: гемодинамика, прогноз, реакция, гелиотропный, старение, импактация, гипотензия, заболевание, дифференцированный подход.

The protection of human health is a priority area of state social policy in Uzbekistan. Gaining more and more widespread, arterial hypertension $(\mathrm{AH})$ today occupies a leading position in the structure of the general morbidity and mortality of the population. According to the latest data from the Cardiology Center of the Ministry of Health of the Republic of Uzbekistan, this pathology occurs in $32 \%$ of the adult population of our country (Kurbanov R.Sh., 2011).

A meta-analysis of numerous studies on the study of hypertension showed that an increase in blood pressure for every $6 \mathrm{mmHg}$ increases the risk of stroke by $40 \%$, myocardial infarction (MI) by $20 \%$ (Bragin A.U., 2010). According to the latest data, 972 million 
people, i.e. $26.4 \%$ of the world's adult population suffers from hypertension. At the same time, 333 million people account for economically developed countries and 639 million people - in developing countries. The highest prevalence of hypertension is noted in Eastern Europe and Latin America. By 2025, an increase in the number of people suffering from hypertension is expected to reach 1.056 million people, i.e. up to $29 \%$ of the world's adult population (Aswini Dutt R., Satish Kumar N.S., Ramaswamy C. at al., 2011).

One of the promising areas in this regard is the study of hypertension from the perspective of adaptation and disadaptation. For, a change in hemodynamics in response to the effects of external and internal factors is a reflection of the adaptive restructuring of the cardiovascular system (CVS), and persistent hypertension is the result of a violation of adaptation.

At present arterial hypertension ( $\mathrm{AH})$, no doubt, is one of the acute problems of modern medicine $[1 ; 3$; $14 ; 15 ; 16]$. As a widespread disease AH today gains leading position in the structure of general disease and mortality of the population. Though there are a lot of data indicative of close interlink between $\mathrm{AH}$ and external environment factors $[2 ; 12 ; 16]$ been accumulated, nevertheless, mechanisms of $\mathrm{AH}$ exacerbation and progression under the influence of meteorological and heliogeophysical factors still have not been completed yet. No concrete criteria for differentiated approach towards rending assistance and prophylaxis of a disease exacerbation developing under unfavorable weather conditions exist.

New perspectives in investigation of adaptivedisadaptive processes under stressor influence of $\mathrm{AH}$ patients are linked with evidence availability of functional connection between breach of vegetative regulation of sinusoid rhythm and destabilization of arterial (blood) pressure (BP) [4; 5]. Vegetativehumoral regulation plays a key role in adaptationcompensative reactions of organism as well as in formation of any pathological process [5; 7]. From the abovementioned, the following aim is put before in this article: to investigate bisoprolol and moxonidin influence character $\mathrm{n}$ central hemodynamic state and their hypertensive effectiveness on $\mathrm{AH}$ patients under various heliogeophysical conditions.

Material and Methods of Investigation

To realize the aim put before 49 patients aged from 32 to 60 years old with II-stage hypertensive disease (average age 51,2 +/- 0,47 years old) with disease durance from 7 to 13 years have been examined at the Bukhara Cardiology Center. Diagnosis verification was made on the basis of WHO/ ISH (1999) and GNC-VI classification.

In order to define indices of systolic and diastolic functions of the left ventricle (LV) echocardiography and Doppler-Echocardiography on Aloka-SSD-350 ultra-sound apparatus with the help of multi-frequency 2,1-2,5 Мгц trans-dicer was made. Echocardiography was realized in accordance with recommendations of the American Association of echocardiography (ASE) in $B$ and $M$ regimes lying down on left side $[6,11]$. In
M-regime the following indices were calculated from long axis parasternal access [8]: diameter of the left atria, end-diastolic and end-systolic diameter of the left ventricle (EDD LV, ESD LV,), of intra-ventricular septum and that of posterior wall of the left ventricle into systole and diastole (IVSs, PWLVs, IVSd, PWLVd), thickness of the right ventricle into diastole (TRVd), and separation index of front side of the mitral valve.

End-diastolic (EDV) and end-systolic volume (ESV) were calculated according to the formula Teiccholz L.E. [12], stroke volume of (SV) left ventricle was defined according to EDV and ESV difference, fraction ejection of the left ventricle was calculated due to formula ФВлж= (EDV lv- ESV lv)/ EDV lv $100 \%$. Having defined surface body area (m2 due to Dubua monogram we have clarified heart index. Also, according to the formula minute blood volume(MBV), general peripheral vessel resistance(GPVR), miocarda mass of the left ventricular was defined.Doppler-electrocardiography was realized in impulse regime due to standard method $[8,9,10]$. Maximal speed of early and atria filling were clarified and calculated. Arterial pressure was measured due to N.S.Korotkov method, average arterial pressure (AP) was calculated according to $\mathrm{Xi}$ Kem formula: BPaverage $=[(\mathrm{SBP}-\mathrm{DBP}) / 3]+\mathrm{dbp}$ (mm.Hg). Geomagnetic situation data was given from the "Uzgidromet". Geomagnetic situation was valued due to K-index, and, alongside with this, were cleared out: quiet days - K-index 0-3 points (GMA-0), geomagnetic disturbance days - K-index 4-6 points(GS), magnetic storm days - K-index 7-9 points(MS).

A week before observation hypertensive preparations were abolished (stopped) to all the patients; if need be, intramuscular dibazol injections were used in order to correct high level of AP. Initially 35 patients with hypertensive disease were examined, and they were divided into 2 groups by method of accidental selection taking into consideration further therapy. I-group (17 patients) who took bisoprolol (Konkor "Merk", Germany) with initial doze - 0,5 ml. gr.

II-group (18 patients) - they used moxonidin (Physiotenz "Solway Farm", Germany) with initial doze - 0,4 ml.gr. In the long run bisoprolol and moxonidin dozes were titrated each two weeks up to gaining aimed meanings at SBP (130 mm.Hg) and DBP ( $80 \mathrm{~mm} . \mathrm{Hg}$.), or lowering of the average arterial pressure (ABP) to $10 \%$ and more. Average dose of bisoprolol was $6,2=-0,4 \mathrm{mg}$ and moxonidin $-0,5+-$ $0,04 \mathrm{mg}$.

Statistical treatment of the results gained was made on personal computer of IBM/PC/AT type using package of standard electronic program "Biostatic for Windows, version 4,03". Parameters were described in M+-б form while meanings distribution group comparisons of variable quantity were made using variation statistical criterion of Student (+). In data analysis pair Student criterion was used. Statistical authenticity was considered to be proved in $\mathrm{P}<0,005$.

Investigation Results 
After the treatment has ended in both I- and IIgroups in different geomagnetic days, statistically trustworthy average arterial pressure was registered in comparison with those of the pre-cure period. But in group-II the level of average arterial pressure in quiet geomagnetic days was relatively low, and its reaction to GS and MS answer was less expressive than in Igroup. At the same time, if in I-group average arterial pressure was lower on $8,7 \%, 13,7 \%$ and $6,7 \%$ in GMA$0, \mathrm{GS}$ and MS days, accordingly, and in II-group difference of this index, accordingly, was $10,3 \%$, $16,1 \%$ and $12,45 \%$.

Essential difference between the two groups is clearly seen in the plane of effectiveness of preparations used on dynamics of DBP changes. Moreover, statistically trustworthy lowering of DBP with bisoprolol used was achieved only in GMA-0days. In moxonidin group after the treatment course statistically trustworthy lowering of DBP was reached in geomagnetic quiet days and in GS and MS days as well; GMA-0 DBP was lower than $11,7 \%(\mathrm{P}<0,001)$, and in GS days - lower than $12,2 \%(\mathrm{P}<0,001)$. Both preparations considerably influenced average arterial pressure, though according to this index moxonidin effectiveness was expressive in comparison with bisoprolol.

In GMA-0 days in I-group after treatment average arterial pressure was lower on $8,8, \%(\mathrm{P}<0,05)$, then in II-group it was lower on $9,3 \%(\mathrm{P}<0,01)$. In GS days this index in I-group was lower on $10,5 \%(\mathrm{P}<0,01)$, in II-group it was lower on $13,5 \%(\mathrm{P}>0,001)$.

Preparations under examination could also stave off excessive increase of the average arterial pressure under MS influence, and moxonidin effectiveness was more expressive. Average arterial pressure those days was lower on $11,6 \%(\mathrm{P}<0,00)$ while after bisoprolol treatment it was lower on 7,5\% $(\mathrm{P}<0,01)$. Made known arterial pressure changes were followed by different character of central hemodynamic indices' changes. In I-group arterial pressure lowering was followed by heart ejection bring down. In this group in GS days $\Phi B$ statistically trustworthy was lower on $5,9 \%$, and in MS days - lower on 6,5\% (P<0,005). In GMA-0 and GS days in I-group after the treatment has been finished blood minute volume statistically trustworthy lowered on $7,2 \%$ and $6,9 \%(\mathrm{P}<0,05)$, accordingly. Bring down of this index to $4,8 \%$ in MS days does not differ statistically trustworthy.

Lowering of heart ejection after the treatment was marked in the II-group also. But, SV,EF and MBV indices displace was not statistically trustworthy. As a result of the treatment it was cleared out that there was peripherical vessels reaction of different character in answer to changes of geomagnetic situation. In bisoprolol group in days of GMA-0 GPVR was lower on $3,3 \% \quad(\mathrm{P}<0,05)$. This preparation promoted statistically trustworthy lowering of vessels reaction to GS answer as well (on 5,4\%, $\mathrm{P}<0,05$ ). But, GPVR lowering in this group in МБ days doesn't differ statistically trustworthy. On the phone of these results moxonidin effect meaning lowering peripherical vessels' reaction in geomagnetic activity reinforcement looks more impressive. Evidence of this is GPVR lowering in GMA-Odays on 5,5\% (P<0,001); in GS days on $9,9 \%(\mathrm{P}<0,001)$ and in $\mathrm{MS}$ days on $8,9 \%$ $(\mathrm{P}<0,001)$.

Examination of diastolic function shows its improvement after the treatment has finished, and that is seen in reduction of early diastolic filling and prolongation of adrial systole. Heart rate reduction in both groups after the treatment is not of trustworthy character. As a result, 6-month period of treatment of patients with hypertension disease using bisoprolol and moxonidin promotes achievement of hypertensive effect not only in geomagnetic-quiet days, but also in days of geomagnetic activity. Such a characteristic was more expressive in moxonidin. Achievement of hypertensive effect is realized through various character of indices change of hemodynamic. Lowering of heleometeotrop reaction of heart-vessel system using bisoprolol is predominantly due to lowering of heart ejection, and while treatment with moxonidin is due to GPVR lowering.

\section{Discussion}

Despite successful introduction of the worked out and adopted standard of hypertonic disease treatment into the clinical practice, actuality of the problem of prophylaxis of this disease complications is still present. Up to the present the level of complications from the side of target organs, and first of all of brain and heart, as a result of sharp increase of arterial pressure under the influence of external factors, i.e. strengthened geomagnetic activity, is still high.

A perspective direction in this plane is investigation of effectiveness of separate preparations in accordance with the character of vegetativehemodynamic interrelations. This is conditioned, on the one hand, by significance of such an interrelation in MS development, and, on the other hand, in realization of heliometeotrop reaction of organism. From this position it is of interest to search deeply into the effectiveness of $\boldsymbol{\beta}$-adrenoblocator - bisoprolol and agonist1 - imidazolin receptors - moxonidin, i.e. investigation of hypertensive effect by way of influence on autonomous and central contour of vegetative regulation.

Results of the very investigation state that bisoprolol possesses essential hypertensive effect, i.e. ability to avert sharp arterial pressure increase due to various power of influence of geomagnetic activity. The most expressive action of the preparation was displayed in ABP lowering. Comparatively trustworthy lower indices of ABP were registered after 6-month treatment by bisoprolol in GMA-0 days, as well as in GS and MS days.

Those days were registered essentially low average arterial pressure indices. Though there was a weak positive DBP reaction. Such results of arterial pressure using bisoprolol were reached, first of all, by lowering of heart ejection. Trustworthy low was EF in GMA-0 and GS days. Making low SV and HR bisoprolol promotes essential break down of MBV. But in MS days such an action of the preparation is not effective enough. Low BP levels with geomagnetic activity also linked with lowering of GPVR though in such a plane bisoprolol in MS days was not enough 
effective. In comparison with bisoprolol moxonidin possessed more expressive influence on hemodynamic in different days of geomagnetic activity, and the result of this are trustworthy low indices of SBP, DBP and ABP. Such a hypertensive effect of moxonidin is conditioned mainly by GPVR lowering due to moderate lowering of the heart ejection.

Conclusions

1. In geomagnetic activity days hypertensive effect of moxonidin in patients with hypertonic disease was more expressive than the effect of bisoprolol.

2. Hypertensive effectiveness of moxonidin in days of geomagnetic activity is conditioned mainly by GPVR lowering while that of bisoprolol is conditioned by lowering of heart ejection.

\section{References}

1. Бильченко А.В. Взаимосвязь автономной регуляции и диастолической функции левого желудка у больных гипертонической болезнью по данным анализ вариабельности сердечного ритма // Вестник. Харьковский национальный университет.- 2002.-№546.- С.13-16.

2. Брагина А.Е. Современные позиции бетаадреноблокаторов в кардиологии: от рекомендаций к реальной практике // Лечащий врач.-2010.- М.№7.- С.50-54.

3. Бреус Т. Когда возмущается космическая погода. Сердце и сосудистая система - главные мишени геомагнитных бурь: Мед.газета.- М., 2005.№ 25 (6 апр.).- С.10.

4. Сафронова Н. Изменения климата: масштаб угрозы // Медицинский вестник. 2004. № 11. С.12.

5. Солошенко О. Артериальная гипертензия и метеозависимость : в поисках верного решения // Арт. Гиперт. 2011. №2(82)III-IV. C.10-17.

6. Фейгенбаум X. Эхокардиография 5-е издание. - М.: Видар, 1999.

7. Beewers D.G. The end of beta blokers for uncomplicated hypertention? Lancet 2005; 366: 15101512.

8. Devereux R.B.,Lunas E.M.,Kasale P.N. et al. Standartization of M-mode echocardiographic left ventricular anatomic measurements. J.Am Cjll Cardiol. 1984; 4:1222-1230.

9. Hatle L., Angelsen B. Doppler Ultrasound in Cardiology. Physical principles and clinical application.-Philadelphia,1985: 74-153.

10. Standarts of measurement, physiological interpretation and clinical use. Task Force of the European Society of Cardiology and the North American Society of Pacing and Electrophysiology //Europ. Heart J. -1996.-Vol.17.-P. 354-381.

11.Stork Th.K., Muller R.M., Piske J. et al/ Noninvasive measurement of left ventricular filling pressure by means of transmitral pulsed Doppler ultrasound. Am.J. Cardiol., 1989;64: 655-660.

12. Azcárate $\mathrm{T}$, Mendoza $\mathrm{B}$. Influence of geomagnetic activity and atmospheric pressure in hypertensive adults. Int J Biometeorol. 2017 Sep;61(9):1585-1592. doi: 10.1007/s00484-017-1337x. Epub 2017, Mar 30.

13. Azcárate T. Мендоса В. Влияние геомагнитной активности и атмосферного давления у взрослых с гипертонической болезнью. // Int J Biometeorol. 2017 сентябрь; 61 (9): 15851592. doi: 10.1007 / s00484-017-1337-x. Epub 2017 30 марта.

14. Joseph M. Caswell, Trevor N. Carniello \& Nirosha J. Murugan. Annual incidence of mortality related to hypertensive disease in Canada and associations with heliophysical parameters//International Journal of Biometeorology. Vol.60, pages 9-20 (2016)

15. Michael A.Persinger ${ }^{\mathrm{c}}$. Experimental simulation of the effects of sudden increases in geomagnetic activity upon quantitative measures of human brain activity: Validation of correlational studies. https://doi.org/10.1016/j.neulet.2012.03.054

16. Azcárate $\mathrm{T}^{1}$, Mendoza $\mathrm{B}^{2}$. Influence of geomagnetic activity and atmospheric pressure in hypertensive adults. //Int J Biometeorol. 2017 сентябрь; 61 (9): 1585-1592. doi: 10.1007 / s00484017-1337-х. Epub 2017, 30 марта. 